\title{
Comparative Analysis of Some Garlic Varieties under Drought Stress Conditions
}

\author{
A. E. Badran ${ }^{1}$ \\ ${ }^{1}$ Genetic Resources Department, Desert Research Center, Cairo, Egypt \\ Correspondence: A. E. Badran, Genetic Resources Department, Desert Research Center, Cairo, Egypt. E-mail: \\ dr.ayman_badran@yahoo.com
}

Received: July 9, 2015 Accepted: August 10, 2015 Online Published: September 15, 2015

doi:10.5539/jas.v7n10p271 URL: http://dx.doi.org/10.5539/jas.v7n10p271

\begin{abstract}
Currently in Egypt the tendency is to counteract some negative effects caused by the climatic, edaphic changes and political conflicts on the Nile River water. So, the field experiment was carried out to provide a review of differential responses for four cultivars and adaptations under three levels of drought stress during two growing seasons (2012/2013 and 2013/2014). According to drought resistance indices i.e., drought tolerance index, yield injury $\%$, superiority measure and relative performance, Egaseed 1 was the most tolerant cultivar of deficit water while Balady was the most sensitive cultivar. According to the stability analysis, Egaseed 2 followed by Sids 40 were the most stable cultivars while Balady cultivar was the lowest stability for bulb weight per plant under different environments conditions. Five ISSR primers used successfully of four garlic varieties under investigation with $50.83 \%$ of mean polymorphism and only three primers (HB08, HB11 and 44B) recorded unique bands. Based on the results of ISSR markers can be used in distinction among the four tested garlic cultivars across any breeding program.
\end{abstract}

Keywords: garlic, drought, resistance indices, stability, ISSR

\section{Introduction}

Garlic (Allium sativum L.) belongs to Alliaceae family, genus Allium is ranked the second most widely used cultivated bulb crop after onion. Although native to central Asia, garlic was grown and consumed in Egypt as early as 2780 B.C. (Yamaguchi, 1983). Garlic is grown all over the world from temperate to subtropical climates (Fritsch \& Friesen, 2002). Production and world cultivated area have increased over years. According to the production data from FAOSTAT for the year 2012, the total production of Garlic was nearly 24 million tones of which about $80 \%$ is from China. India, South Korea, Egypt, Russia, Myanmar, Ethiopia and United States are the other countries leading in garlic production. The lack of sexual reproduction in garlic limits the increase of variability that is useful for economically important traits breeding, such as tolerance to biotic and abiotic stress, earliness, yield and quality. Moreover, vegetative propagation has various disadvantages, which can cause a yield decrease of up to $70 \%$ and loss of product quality (Nagakubo et al., 1993; Kamenetsky, 2007). It has been established that drought stress is a very important limiting factor at the initial phase of plant growth and development. It affects both elongation and expansion growth (Shao et al., 2008). Greater plant fresh and dry weights under water limited conditions are desirable characters. A common adverse effect of water stress on crop plants is the reduction in fresh and dry biomass production (Farooq et al., 2009). Plant breeding programs mostly focused on developing high yielding genotypes. But recently, stable and sustainable yield under diverse environmental conditions are the major aim of plant breeders in a crop improvement program. Generally, Lin et al. (1986) identified three concepts of stability: Type 1, a genotype is considered to be stable if its among-environment variance is small; Type 2, a genotype is considered to be stable if its response to environments is parallel to the mean response of all genotypes in the trial; Type 3, a genotype is considered to be stable if the residual MS from the regression model on the environmental index is small. In the same manner, Becker and Léon (1988) called the type 1 of stability a static, or a biological concept of stability while called this stability of both type 2 and 3 the dynamic or agronomic concept of stability. Polymorphism of molecules such as isozymes and DNA can be used to characterize plant germplasm, especially in cases where morphological and biochemical differences are not conspicuous. Although isozymes analysis represented the first application of molecular markers in the genus Allium, its main drawback is the low number of enzymatic systems available in 
garlic. In addition, these markers may suffer changes induced by the developmental stage of plant material analyzed and by environment (Pooler \& Simon 1993; Klaas \& Friesen, 2002). DNA-based markers are less affected by age, physiological condition of the sample and environmental factors. They are not tissue specific and can be detected in any developmental stage of an organism. The use of molecular markers is indispensable for the establishment of essence collections that should contain unique, varied and completely identified accessions in order to reduce costs and effort required for maintenance of collections in situ (Ipek et al., 2008).

There is a lack of information pertaining to garlic growth under drought stress conditions. Our objective is to provide a review of plant responses and adaptations through the studying of genetic diversity of tested garlic cultivars under drought stress conditions using some different parameters.

\section{Material and Methods}

\subsection{Field Experiment and Plant Material}

The present work was carried out at El Salhia region, Al Sharkia, Egypt during two growing seasons 2012/2013 and 2013/2014. Four economical Egyptian garlic (Allium sativum L.) varieties (Balady, Sids 40, Egaseed 1 and Egaseed 2) has been evaluated under three irrigation levels i.e., normal irrigation where the quantity of water applied for each plot was calculated according to Khurmi (1984) and drought stress was imposed after 30 days from planting by reducing available water supply by 25 and $50 \%$ via irrigation tapes. The experiment consisted of three irrigation treatments during two seasons (six environments) and four varieties replicated four times in a randomized split-plot design, with drought levels as main plots and tested cultivars as subplots.

\subsection{Pre-Planting Treatment and Fertilization}

A $25 \mathrm{~m}^{3}$ of manure was applied to the soil during preparation and before garlic plantation where the soil of the experimental was sandy loam having $\mathrm{pH}$ 7.7. While, NPK chemical fertilizer recommended for garlic cultivation were applied as follow: $120 \mathrm{~kg}$ ammonium sulphate, $65 \mathrm{~kg}$ super phosphate and $100 \mathrm{~kg}$ potassium chloride. Bulbs were carefully separated into individual cloves. Then, the cloves were soaked in tap water for $24 \mathrm{~h}$ to enhance sprouting.

\subsection{Measurements and Estimates of Plant}

Characteristics of plant growth were measured as follow:

1) Plant height $(\mathrm{cm})$ at harvest (from the surface of soil to the highest point of plant).

2) Fresh weight per plant ( $g /$ plant) after harvest.

3) Dry weight per plant [the samples dried in oven at $70{ }^{\circ} \mathrm{C}$ for 48 hours and weighed by sensitive balance (g/plant)].

4) Bulb diameter (cm) calculated according to Mann (1952).

5) Amount of chlorophyll (SPAD units) was measured using chlorophyll Meter SPAD-502 that is widely used for the quick, accurate and without causing harm of the amount of chlorophyll present in the leaf.

6) Bulb weight (g) were harvested when the leaves turned yellowish and left in air for three weeks after the harvesting.

\subsection{Statistical Analysis}

Drought tolerance measurements were calculated as follow:

1) Drought tolerance index $(\mathrm{DTI}): \mathrm{DTI}=(\mathrm{Yp}) \times(\mathrm{Yd}) /(\mathrm{Y} \mathrm{p})^{2} \quad($ Fernandez, 1992);

2) Yield injury \% (YI): YI $=(\mathrm{Yp}-\mathrm{Yd}) / \mathrm{Yp} \times 100 \quad$ (Blum, 1983b);

3) Superiority measure (SM): $\mathrm{SM}=\mathrm{Yd} / \mathrm{Yp} \quad$ (Lin \& Binns, 1988);

4) Relative performance (RP): $\mathrm{RP}=(\mathrm{Yd} / \mathrm{Yp}) / \mathrm{R} \quad$ (Abo-Elwafa \& Bakheit, 1999).

Where, $\mathrm{Yp}=$ yield of cultivar under normal conditions; $\mathrm{Yd}=$ yield of variety under drought stress conditions; Ýp = Mean yield of all varieties under normal conditions; $Y$ d = Mean yield of all varieties under drought stress conditions; $\mathrm{R}=(\mathbf{Y} \mathrm{d} / \mathrm{Ý} \mathrm{p})$.

The genetic stability parameters were calculated for bulb weight as suggested by Eberhart and Russell (1966) used the following model to study the stability of varieties under different environments: $Y i j=m+B i j j+\delta i j$. Two parameters of stability were calculated: a) The regression coefficient (bi); b) Mean square deviations ( $\mathrm{S}^{2} \mathrm{di}$ ) from linear regression. Where, $\sum \mathrm{Ij}=0, \sum \mathrm{bi} / \mathrm{n}=1$. Where, $\mathrm{Ij}$ is environmental index, $\mathrm{n}$ is number of varieties.

The statistical analysis (LSD) at $5 \%$ level of probability was used for comparing the mean performance of four 
tested garlic varieties under three soil moisture stress during two growing seasons (six environments) according to K. A. Gomez and A. A. Gomez (1984).

\subsection{DNA Extraction, ISSR-PCR and Data Analysis}

Genomic DNA was extracted by CTAB from young and fresh leaves ( 5 samples chosen randomly) which were collected separately for the four cultivars of garlic plants using the method of J. J. Doyle and L. J. Doyle, (1990). The extracted genomic DNA was tested for purity index (A260/A280 absorbance ratio) on UV-VIS Spectrophotometer and for size, purity, and safety. A 1.8 (A260 nm/A280 nm) ratio of extracted DNA samples indicates their high purity (Sambrook et al., 1989). For ISSR-PCR reactions, five specific primers as presented in Table 6 synthesized by Metabion Germany were used according to Sharma et al. (1995) for garlic tested cultivars. $15 \mu \mathrm{L}$ of PCR- products were resolved in $1.5 \%$ agarose gels electrophoresis according to Sambrook et al., 1989. All bands resulting from ISSR gels were detected on an UV-transilluminator filter and photographed using Gel documentation system UVP2000. DNA bands generated by each primer were counted and their molecular sizes were compared with those of the DNA markers. The bands scored from DNA profiles generated by each primer were pooled together. Then, DNA bands were scored as present (1) or absent ( 0$)$ for all tested primers. Software data analysis for Bio-Rad 620 USA densitometer was used to compare between tested cultivars.

\section{Results}

\subsection{Mean Performance of All Tested Traits}

Results in Table 1 showed that, tested garlic varieties responded differently to the different environmental conditions, suggesting the importance of assessment of varieties under different environments in order to identify the best cultivar make up for each particular environment. Also, the present data clearly indicated that, the average of all tested traits was enhanced for plants grown under Env.4 (normal irrigation conditions during the second season) compared with the other environments. Moreover, the results indicated the superiority of Balady cultivar under both stress and non-stress conditions for plant height trait. According to amount of chlorophyll, superiority was of Balady cultivar under non stress conditions (80.50 under Env1. and 81.03 under Env.4 conditions) while the best cultivars under high stress conditions (Env.3 and Env.6) were Egaseed 2 and Egaseed1 (64.40 and 69.00 respectively). For the other traits, i.e., bulb diameter, fresh weight, dry weight and bulb weight the data showed the superiority of Egaseed 1 under high stress conditions (Table 1). 
Table 1. Interaction between tested cultivar and the six environments for all traits

\begin{tabular}{|c|c|c|c|c|c|c|}
\hline $\begin{array}{l}\text { Varieties x Environments } \\
(G * E)\end{array}$ & $\begin{array}{l}\text { Plant height } \\
\text { (cm) }\end{array}$ & $\begin{array}{l}\text { Amount of } \\
\text { chlorophyll } \\
\text { (SPAD units) }\end{array}$ & $\begin{array}{l}\text { Bulb diameter } \\
(\mathrm{cm})\end{array}$ & $\begin{array}{l}\text { Fresh weight } \\
\text { (g) }\end{array}$ & $\begin{array}{l}\text { Dry weight } \\
\text { (g) }\end{array}$ & $\begin{array}{l}\text { Bulb weight } \\
\text { (g) }\end{array}$ \\
\hline Balady x Env.1 & 84.25 & 80.30 & 6.50 & 175.73 & 41.20 & 64.25 \\
\hline Sids 40 x Env.1 & 73.75 & 78.28 & 6.10 & 169.35 & 39.30 & 62.50 \\
\hline Egaseed 1 x Env.1 & 72.75 & 76.85 & 6.45 & 181.25 & 46.00 & 66.50 \\
\hline Egaseed 2 x Env.1 & 80.00 & 74.88 & 5.58 & 173.88 & 34.68 & 63.88 \\
\hline Balady x Env.2 & 80.30 & 75.90 & 5.95 & 162.25 & 25.33 & 47.50 \\
\hline Sids $40 \times$ Env. 2 & 71.50 & 72.30 & 5.50 & 158.18 & 25.34 & 50.50 \\
\hline Egaseed 1 x Env.2 & 70.00 & 71.75 & 5.70 & 163.43 & 34.33 & 58.10 \\
\hline Egaseed 2 x Env.2 & 76.00 & 70.78 & 4.80 & 152.68 & 28.53 & 54.25 \\
\hline Balady x Env.3 & 74.13 & 58.93 & 5.25 & 142.00 & 21.25 & 39.38 \\
\hline Sids 40 x Env. 3 & 65.50 & 56.85 & 4.65 & 138.00 & 25.08 & 40.73 \\
\hline Egaseed 1 x Env.3 & 62.75 & 64.28 & 5.35 & 153.25 & 31.05 & 45.31 \\
\hline Egaseed $2 \times$ Env.3 & 70.00 & 64.40 & 4.18 & 140.00 & 25.85 & 40.00 \\
\hline Balady x Env.4 & 86.25 & 81.03 & 6.50 & 169.00 & 53.00 & 66.25 \\
\hline Sids 40 x Env.4 & 74.75 & 78.98 & 6.00 & 173.50 & 62.72 & 87.25 \\
\hline Egaseed 1 x Env-4 & 75.00 & 78.63 & 6.95 & 216.97 & 64.79 & 96.73 \\
\hline Egaseed 2 x Env.4 & 81.75 & 75.58 & 6.00 & 192.50 & 51.97 & 82.40 \\
\hline Balady x Env.5 & 78.00 & 77.40 & 6.00 & 137.63 & 48.48 & 55.13 \\
\hline Sids 40 x Env.5 & 71.00 & 73.15 & 5.33 & 156.83 & 50.25 & 74.75 \\
\hline Egaseed 1 x Env.5 & 70.00 & 73.25 & 6.50 & 186.00 & 54.37 & 85.35 \\
\hline Egaseed 2 x Env.5 & 77.00 & 70.78 & 4.95 & 159.23 & 45.46 & 70.00 \\
\hline Balady x Env.6 & 71.00 & 63.25 & 5.35 & 131.00 & 44.16 & 44.27 \\
\hline Sids 40 x Env.6 & 66.00 & 66.00 & 4.50 & 152.00 & 47.43 & 60.21 \\
\hline Egaseed 1 x Env.6 & 62.75 & 69.00 & 5.80 & 176.00 & 47.40 & 70.00 \\
\hline Egaseed $2 \times$ Env.6 & 70.00 & 63.00 & 4.33 & 159.00 & 38.97 & 51.48 \\
\hline LSD (0.05) & 1.241 & 1.296 & 0.140 & 1.183 & 0.648 & 0.797 \\
\hline
\end{tabular}

\subsection{Resistance Indices of Tested Varieties}

Stress resistance indices were studied to evaluate garlic cultivars under deficit water stress condition. Bulb weight per plant of the four varieties under both non-stress and stress conditions were measured for calculating different sensitivity and tolerance indices (Table 2). In the same context, drought tolerance index (DTI) selected Egaseed 1 as the most relatively tolerant cultivar according to bulb weight (0.729 and 0.979) while Balady cultivar was the least relative tolerant (0.612 and 0.424) during 2012/2013 and 2013/2014 growing seasons respectively. Based on yield injury (\%) Balady cultivar recorded the highest deficiency in bulb weight during 2012/2013 (38.716) followed by Egaseed 2 cultivar during 2013/2014 growing season (37.530). According to superiority measure (SM) and relative performance (RP), each of Sids 40 and Egaseed 1 cultivars were recorded values higher than the means value of all cultivars while Balady and Egaseed 2 were exhibited less than the means value (0.643 and 0.677$)$ and (1.000 and 0.996) during two growing seasons respectively (Table 2$)$. The results in Table 2 indicated that, the cultivars can be categorized into three groups based on their performance indices of bulb weight in drought stress and non-stress conditions: Group a) Egaseed 1 cultivar express uniform superiority in both drought stress and non-stress conditions (66.50, 96.73 and 45.31, 70.00 respectively during two the seasons), Group b) Sids 40 cultivar located in medium of performance indices while, both of Balady and Egaseed 2 varieties (Group c) perform poorly under stress conditions for bulb weight per plant during growing seasons. 
Table 2. Tolerance indices of tested garlic cultivars under stress and non-stress condition during the two seasons for bulb weight

\begin{tabular}{|c|c|c|c|c|c|c|c|c|c|c|c|c|}
\hline \multirow[b]{2}{*}{ Cultivars } & \multirow{2}{*}{$\begin{array}{l}Y p \\
2012 / \\
2013\end{array}$} & \multirow{2}{*}{$\begin{array}{l}\text { Yp } \\
2013 / \\
2014\end{array}$} & \multirow{2}{*}{$\begin{array}{l}\text { Yd } \\
2012 / \\
2013\end{array}$} & \multirow{2}{*}{$\begin{array}{l}\text { Yd } \\
2013 / \\
2014\end{array}$} & \multicolumn{2}{|c|}{ DTI } & \multicolumn{2}{|c|}{ YI (\%) } & \multicolumn{2}{|c|}{ SM } & \multicolumn{2}{|c|}{$\mathbf{R P}$} \\
\hline & & & & & $\begin{array}{l}2012 / \\
2013\end{array}$ & $\begin{array}{l}2013 / \\
2014\end{array}$ & $\begin{array}{l}2012 / \\
2013\end{array}$ & $\begin{array}{l}2013 / \\
2014\end{array}$ & $\begin{array}{l}2012 / \\
2013\end{array}$ & $\begin{array}{l}2013 / \\
2014\end{array}$ & $\begin{array}{l}2012 / \\
2013\end{array}$ & $\begin{array}{l}2013 / \\
2014\end{array}$ \\
\hline Balady & 64.25 & 66.25 & 39.38 & 44.27 & 0.612 & 0.424 & 38.716 & 33.177 & 0.613 & 0.668 & 0.953 & 0.984 \\
\hline Sids 40 & 62.50 & 87.25 & 40.73 & 60.21 & 0.616 & 0.760 & 34.840 & 30.989 & 0.652 & 0.690 & 1.013 & 1.016 \\
\hline Egaseed 1 & 66.50 & 96.73 & 45.31 & 70.00 & 0.729 & 0.979 & 31.868 & 27.630 & 0.681 & 0.724 & 1.059 & 1.065 \\
\hline Egaseed 2 & 63.88 & 82.40 & 40.00 & 51.48 & 0.619 & 0.613 & 37.383 & 37.530 & 0.626 & 0.625 & 0.973 & 0.920 \\
\hline Mean & 64.28 & 83.16 & 41.35 & 56.49 & 0.644 & 0.694 & 35.702 & 32.332 & 0.643 & 0.677 & 1.000 & 0.996 \\
\hline
\end{tabular}

Note. $\mathrm{Yp}=$ bulb weight without non stress; $\mathrm{Yd}=$ bulb weight with high stress; DTI = drought tolerance index; YI $=$ yield injury; $\mathrm{SM}=$ superiority measure; $\mathrm{RP}=$ relative performance.

\subsection{Stability Parameters Analysis}

Data in Table 3 indicated that, garlic varieties responded differently to the different environmental conditions, suggesting the importance of cultivars assessment under different environments (three treatments during two seasons) in order to identify the best genetic make up for bulb weight per plant.

In Table 2, the analysis of variance can be further extended in which the total sum of squares is partitioned into various parts given in Table 4.

In Table 4, the sum of squares due to varieties $\mathrm{x}$ environments is further partitioned into two parts: 1) sum of squares due to variety $\mathrm{x}$ environment (linear) which is in fact the sum of square due to regression and 2) sum of squares due to deviation from linearity of response (i.e., S.S due to pooled deviation).

The stability of tested cultivars performance across environments can be an important consideration in plant breeding program. Stability parameters, regression coefficient and deviation from regression were estimated for bulb weight trait per plant of four tested cultivars through the six environments (three treatments during two seasons). Standard error of regression coefficient, population mean and standard error of mean were also illustrated at Tables 3 and 4. Data presented at Table 4 showed that Egaseed 2 followed by Sids 40 cultivar could be considered as a stable cultivars for bulb weight in different environments, due to the lowest values in sum of deviation squares while Balady cultivar was the lowest stability where recorded the highest deviation square (138.321). As well as Table 5 cleared that, Egaseed 2 followed by Sids 40 cultivar had the lowest deviation mean squares $\left(\mathrm{S}^{2} \mathrm{di}\right)$ and the nearest regression coefficient (bi) to unity (1.006 and 1.119 respectively), while Balady cultivar appear to be the lowest stability according to deviation mean squares and regression coefficient (33.861 and 0.652 respectively). Also Table 5 showed that, Egaseed 1 was medium in stability and the highest in the average of bulb weight $(70.330 \mathrm{~g})$ compared with the mean of all cultivars under all environments (54.789).

According to Eberhart and Russell model, data in Tables 4 and 5 indicate that the most important stability parameter appeared to be the minimum deviation mean square scored Egaseed 2 followed by Sids 40 for bulb weight per plant (i.e., the highest stability) while Balady cultivar had the lowest stability for bulb weight under different environments .

Table 3. Analysis of variance pooled data for bulb weight

\begin{tabular}{lll}
\hline S.O.V & d.f & M.S \\
\hline Varieties (G) & 3 & $1252.33^{* *}$ \\
Environments (E) & 5 & $3464.81^{* *}$ \\
Replicates in Environments & 18 & 4.239 \\
$\mathbf{G} * \mathbf{E}$ & 15 & $129.82^{* *}$ \\
Error & 54 & 2.42 \\
\hline
\end{tabular}

Note. ${ }^{* *}$, significant at $1 \%$ probability level. 
Table 4. Analysis of variance for 4 varieties under 6 different environmental conditions for bulb weight

\begin{tabular}{llll}
\hline Source of variance & d.f. & S.S & M.S \\
\hline Total & 23 & 5757.087 & \\
Varieties (G) & 3 & 939.248 & $313.082^{* *}$ \\
Env. + (varieties x Env.) & 20 & 4817.839 & 240.950 \\
Env.(linear) & 1 & 4331.009 & 4331.009 \\
Variety x Env.(linear) & 3 & 199.950 & $66.650^{*}$ \\
Pooled deviation & 16 & 286.88 & 17.93 \\
Balady & 4 & 138.321 & 34.58 \\
Sids 40 & 4 & 28.398 & 7.100 \\
Egaseed 1 & 4 & 96.123 & 24.03 \\
Egaseed 2 & 4 & 24.039 & 6.10 \\
Pooled error & 72 & 51.804 & 0.720 \\
\hline
\end{tabular}

Note. ${ }^{*}, * *$ significant at $5 \%$ and $1 \%$ probability level respectively.

Table 5. Mean values of bulb weight per plant over environments, regression coefficient (bi) and deviation mean squares $\left(\mathrm{S}^{2} \mathrm{di}\right)$ for 4 varieties

\begin{tabular}{llll}
\hline Varieties & Mean & bi & S di \\
\hline Balady & 52.795 & 0.652 & 33.861 \\
Sids 40 & 62.700 & 1.119 & 6.380 \\
Egaseed 1 & 70.330 & 1.221 & 23.311 \\
Egaseed 2 & 60.334 & 1.006 & 5.290 \\
Mean & 54.789 & 1.000 & - \\
L.S.D. & 0.600 & - & - \\
S.E. (bi) & 0.129 & - & - \\
$\mu(\mathrm{m})$ & 61.539 & - & - \\
S.E. $(\mathrm{m})$ & 1.894 & - & -
\end{tabular}

Note. S.E $(\mathrm{bi})=$ standard error of regression coefficient. $\mu(\mathrm{m})=$ population mean. S.E $(\mathrm{m})=$ standard error of mean.

\subsection{ISSR-PCR and Data Analysis}

Variation in DNA sequences lead to polymorphism which is indicative of genetic diversity. The results in Figure 1 and Table 6 indicated the presence of relative wide genetic variability as a result of the medium polymorphism among the tested garlic cultivars. Five ISSR primers successfully amplified DNA fragments of four garlic cultivars under investigation with total number of 30 fragments producing 13 monomorhic bands and 17 polymorphic bands (unique and non-unique) with $50.83 \%$ of mean polymorphism. In the same manner, polymorphism range was recorded between $0.00 \%$ with $\mathrm{HB} 10$ primer and $75.00 \%$ with $44 \mathrm{~B}$ primer. DNA band size was ranged between 130 bp with $\mathrm{Hb} 08$ primer and 1050 bp with HB11 primer. Figure 1 and Table 7 illustrated that, only three primers (HB08, HB11 and 44B) recorded unique bands (negative and positive) while all tested varieties did not show any unique polymorphic bands with $\mathrm{HB} 10$ and $\mathrm{HB} 13$ primers which recorded the lowest polymorphism $(0.0 \%$ and $50 \%)$. Two unique bands were recorded in Balady cultivar where the first one was positive band (130 bp) with HB08 while the second one was negative band (490 bp) with 44B primer compared with the other tested cultivars. In the same context, Sids 40 recorded one negative band with HB08 primer $(931 \mathrm{bp})$. On the other hand, Egasee1 cultivar recorded four unique bands, one of it was positive band (217 bp) with HB08 primer while, the three others $(302,470$ and $375 \mathrm{bp})$ were negative bands with HB11 primer. But did not record any unique band concerning for Egassed 2 cultivar. Figure 1 and Table 7 showed that, HB10 primer gave the lowest total number of bands while, HB08 and HB 11primers gave the highest total number s of bands. Moreover, Table 6 pointed out it can dependence on HB08 primer in determine positive unique bands (130 and $217 \mathrm{bp)}$ to distinguish both Balady and Egaseed 1cultivars respectively. In general, the results indicated that ISSR markers gave adequate distinction among the four tested garlic cultivars. 

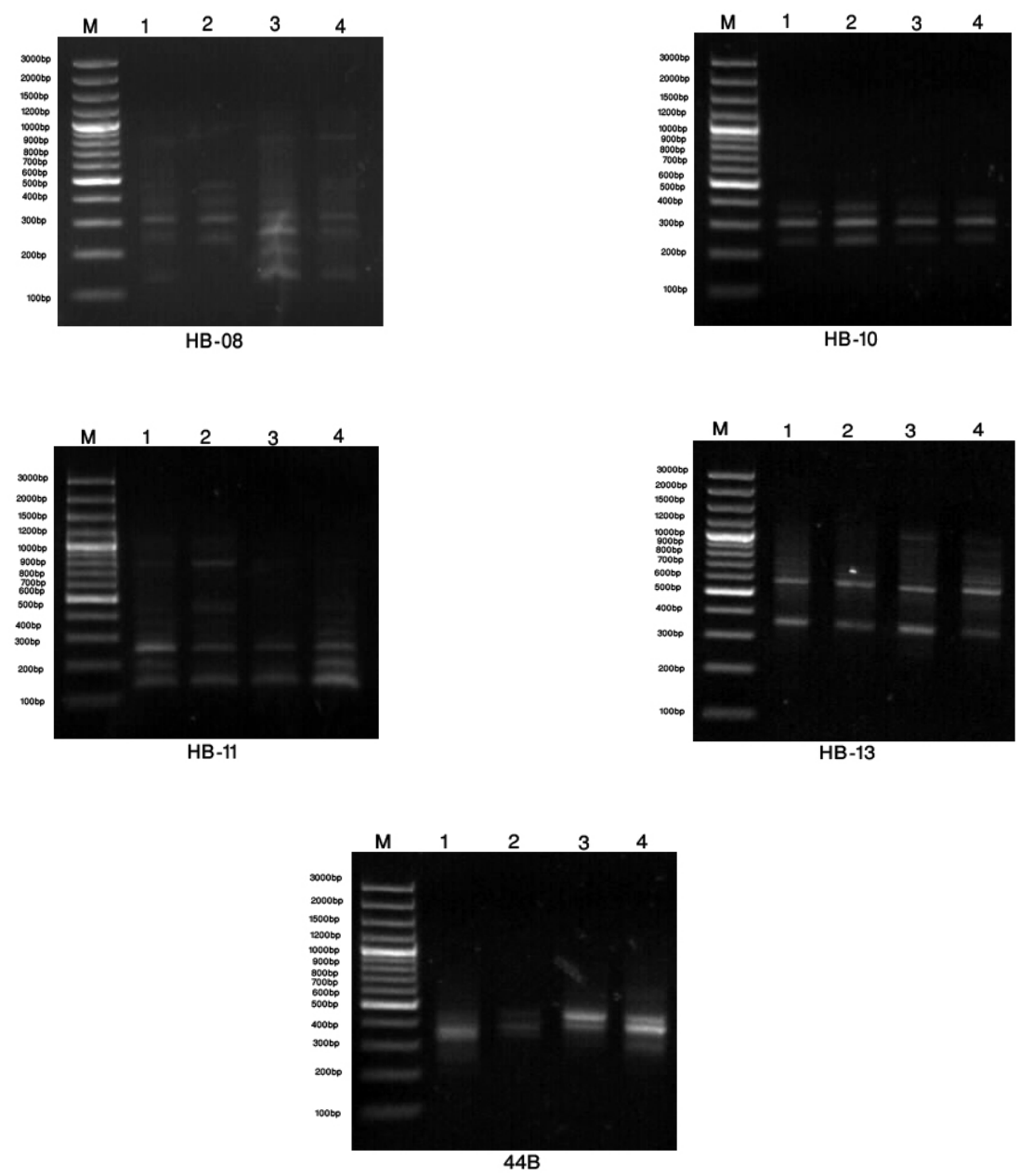

Figure 1. DNA polymorphism using ISSR profiles with five primers of four garlic cultivars

Note. M: marker; 1: Balady cultivar; 2: Sids 40 cultivar; 3: Egaseed 1 cultivar; 4: Egaseed 2 cultivar.

Table 6. List of ISSR primers and their sequences and the number of amplified DNA bands generated by five DNA-ISSR primers used for the identification of four garlic varieties

\begin{tabular}{llllll}
\hline Primer code No. & $\begin{array}{l}\text { Primer sequence } \\
\mathbf{5}^{\prime} \boldsymbol{\prime} \mathbf{3}^{\prime}\end{array}$ & $\begin{array}{l}\text { Total No. of } \\
\text { bands }\end{array}$ & $\begin{array}{l}\text { No. of Monomorphic } \\
\text { bands }\end{array}$ & $\begin{array}{l}\text { No. of polymorphic } \\
\text { bands }\end{array}$ & $\begin{array}{l}\text { Polymorphism } \\
\%\end{array}$ \\
\hline HB-08 & & & & 66.66 \\
HB-10 & $(\mathrm{GT}) 6 \mathrm{GG}$ & 9 & 3 & 6 & 00.00 \\
HB-11 & $(\mathrm{GA}) 6 \mathrm{CC}$ & 3 & 3 & 0 & 62.50 \\
HB-13 & $(\mathrm{GT}) 6 \mathrm{CC}$ & 8 & 3 & 5 & 50.00 \\
44B & GA(GGA) $2 \mathrm{GGC}$ & 6 & 3 & 3 & 75.00 \\
\hline Total & $(\mathrm{CT}) 8 \mathrm{TG}$ & 4 & 1 & 3 & Mean $=50.83$ \\
\hline
\end{tabular}


Table 7. Type and fragment size of five DNA-ISSR primers used for the identification of four garlic cultivars

\begin{tabular}{lllll}
\hline Primer code No & Unique band (bp) & Balady & Sids 40 & Egaseed 1 \\
\hline HB08 & Unique bands & 1 & 0 & 1 \\
& Fragment size (bp) & 130 & 931 & 217 \\
\hline HB11 & Unique bands & & & $0,0,0$ \\
& Fragment size (bp) & & & $302,470,375$ \\
\hline \multirow{2}{*}{ 44B } & Unique bands & 0 & & \\
& Fragment size (bp) & 490 & & \\
\hline
\end{tabular}

The previous results, showed harmony between the stability analysis and ISSR markers where, Egaseed 2 cultivar was the highest stability while did not record any unique band with any used primer. On the contrary, Balady cultivar was the lowest stability and recorded two unique bands.

\section{Discussion}

\subsection{Performance, Resistance Indices and Stability Parameters}

A drought resistant genotype can usefully be defined as one which gives a significantly higher yield than average under water stress conditions. So, the results in Tables 1 and 2 can separate the tested garlic varieties according to yield under both normal and water deficit conditions and these findings are consistent with Pourdad (2008), Pireivatlou et al. (2010), Majidi et al. (2011) and Badran and Moustafa (2014) who noted that stress tolerance index (STI) can be a reliable index for selecting high yielding varieties under both with and without drought stress conditions. In the same context, the data in Table 2 showed three groups based on their performance; cultivar express good performance in both non stress and water stress conditions, cultivars with good performance only under non stress conditions and cultivar express medium performance in both non stress and drought stress conditions. These finding in relative harmony with Fernandez, 1992 who reported that, the genotypes categorized into four group based on their performance in well irrigated and water stress conditions: genotype express good performance in both water stress and non stress conditions (Group 1), genotypes with good performance only in well irrigated conditions (Group 2), genotypes relatively gave higher yield in water stress conditions (Group 3), and genotypes with low performance in both conditions (Group 4).

The mean sum of squares due to G x E (linear) was significant for the average weight of five bulbs and the marketable yield showing that there were large differences among environments for these traits. Similar results were also reported by Kumar et al. (1994). Analysis of variance for stability of different characters of garlic (Allium safivum L.) indicated that mean differences for varieties and environments (years) were significant for all the characters except for number of leaves, indicating that the performance with respect to number of leaves in different years was not stable (Khar et al., 2005). Generally, Eberhart and Russell (1966) reported that the genotype with unit regression coefficient $(b=1)$ and the deviation not significantly different from zero $\left(\mathrm{Sd}^{2}=0\right)$ is said to be the stable one.

\subsection{ISSR-PCR and Data Analysis}

In this work we used ISSR markers to compare garlic varieties in accord with Al-Otayk et al. (2008) who reported that, ISSR technology and RAPD markers are useful tools for analysis of genetic diversity of garlic productive characters. ISSR markers can provide a better approximation to true variation among garlic lines. In the same manner, Jabbes et al. (2011) reported that, there was sufficient diversity detected using ISSR markers in national collection of garlic germplasm which is crucial for the conservation of genetic diversity and its valorization. In the same context, he indicated that, the availability of a relatively high number of polymorphic ISSR markers reflects the heterozygous genome and that ISSR technique is able to detect as much polymorphism in a vegetative as in sexually propagated species. Accordingly, the analyzed accessions were separated into two groups: Tunisian populations group and French clones group.

\section{Conclusion}

The present investigation indicated that, Egaseed 1 cultivar was superiority in performance indices both drought stress and non-stress conditions, Sids 40 cultivar located in medium while, both of Balady and Egaseed 2 varieties perform poorly under stress conditions for bulb weight per plant. On the other hand, stability parameters appeared that, Egaseed 2 was the highest stability cultivar while, Balady cultivar was the lowest 
stability for bulb weight under different environments. Also, genetic diversity using ISSR markers is useful to distinguish among tested garlic cultivars.

\section{References}

Abo-Elwafa, A., \& Bakheit, B. R. (1999). Performance, correlation and path coefficient analysis in faba bean. Assiut J. Agric. Sci., 30, 77-91.

Al-Otayk, S., El-Shinawy, M. Z., \& Motawei, M. I. (2008). Variation in productive characteristics and diversity assessment of garlic cultivars and lines using DNA markers. JKAU: Met., Env. and Arid Land Agric. Sci., 20(1), 63-79.

Badran, A. E., \& Moustafa, E. S. A. (2014). Drought resistance indices and path analysis in some wheat genotypes. World Applied Sciences Journal, 30(12), 1870-1876.

Becke, H. C., \& Léon, J. (1988). Stability analysis in plant breeding. Plant Breeding, 101, 1-23. http://dx.doi.org/10.1111/j.1439-0523.1988.tb00261.x

Blum, A., Poyarkova, H., Golan, G., \& Mayer, J. (1983b). Chemical desiccation of wheat plants as a simulator of postanthesis stress. I. Effects on translocation and kernel growth. Field Crops Research, 6, 51-58. http://dx.doi.org/10.1016/0378-4290(83)90047-3

Doyle, J. J., \& Doyle, J. L. (1990). Isolation of plant DNA from fresh tissue. Focus, 12, 13-15.

Eberhart, S. A., \& Russell, W. A. (1966). Stability parameters for comparing varieties. Crop Sci., 6, 36-40. http://dx.doi.org/10.2135/cropsci1966.0011183X000600010011x

Farooq, M., Wahid, A., Kobayashi, N., Fujita, D., \& Basra, S. M. A. (2009). Plant drought stress: Effects, mechanisms and management. Agron. Sustain. Dev., 29, 185-212. http://dx.doi.org/10.1051/agro:2008021

Fernandez, G. C. J. (1992). Effective selection criteria for assessing plant stress tolerance. Proceedings of the International Symposium on Adaptation of Vegetables and other Food Crops in Temperature and Water Stress (Chapter 25, pp. 257-270). Taiwan.

Fritsch, R. M., \& Friesen, N. (2002). Evolution, Domestication and Taxonomy. In H. D. Rabinowitch \& L. Currah (Eds.), Allium Crop Sciences: Recent Advances (pp. 5-30). CAB International, Wallingford, U.K. http://dx.doi.org/10.1079/9780851995106.0005

Gomez, K. A., \& Gomez, A. A. (1984). Statistical procedures for agricultural research (2nd ed., p. 680). John Willey and Sons, New York.

Ipek, M., Ipek, A., \& Simon, P. W. (2008). Rapid Characterization of garlic clones with locus-specific DNA markers. Turk. J. Agric. For., 32, 357-362.

Jabbes, N., Georiau, E., Le Clerc, V., Dridi, B., \& Hannechi, C. (2011). Inter simple sequence repeat fingerprints for assess genetic diversity of Tunisian garlic populations. Journal of Agricultural Science, 3(4), 77-85. http://dx.doi.org/10.5539/jas.v3n4p77

Kamenetsky, R. (2007). Garlic: Botany and Horticulture. Hort. Rev., 33, 123-171. http://dx.doi.org/10.1002/9780470168011.ch2

Khar, A., Devi, A., Mahajan, V., \& Lawande, K. E. (2005). Genotype x environment interactions and stability analysis in elite lines of garlic (Allium sativum L.). J. Spices and Aromatic Crops, 14(1), 21-27.

Khurmi, R. S. (1984). A text book of hydraulics, fluid mechanics and hydraulic machines. Chand S. and Company Lted., Ram Nagar. New Delhi.

Klaas, M., \& Friesen, N. (2002). Molecular Markers in Allium. In H. D. Rabinowitch \& L. Currah (Eds.), Allium Crop Sciences: Recent Advances (pp. 159-185). CAB International, Wallingford, U.K. http://dx.doi.org/10.1079/9780851995106.0159

Kumar, A., Prasad, B., Saha, B. C., Sinha, R. P., \& Maurya, K. R. (1994). Phenotypic stability in garlic. J. Appl. Biol., 4, 23-26.

Lin, C. S., \& Binns, M. R. (1988). A superiority measure of cultivar performance for cultivar x location data. Can. J. Plant Sci., 68, 193-198. http://dx.doi.org/10.4141/cjps88-018

Lin, C. S., Binns, M. R., \& Lefkovitch, L. P. (1986). Stability analysis: Where do we stand? Crop Sci., 26, 894-900. http://dx.doi.org/10.2135/cropsci1986.0011183X002600050012x

Majidi, M., Tavakoli, V., Mirlohi, A., \& Sabzalian, M. R. (2011). Wild safflower species (Carthamus 
oxyacanthus Bieb.): A possible source of drought tolerance for arid environments. Aust. J. Crop Sci., 5(8), 1055-1063.

Mann, L. K. (1952). Garlic bulb studies. Calif. Agric., 6, 13.

Nagakubo, T., Nagasawa, A., \& Ohkawa, H. (1993). Micropropagation of Garlic Through in vitro Bulblet Formation. Plant Cell, Tiss. Org. Cult., 32, 175-183. http://dx.doi.org/10.1007/BF00029840

Pireivatlou, A. S., Masjedlou, B. D., \& Aliyev, R. T. (2010). Evaluation of yield potential and stress adaptive trait in wheat genotypes under post anthesis drought stress conditions. Afr. J. Agric. Res., 5, 2829-2836.

Pooler, M. R., \& Simon, P. W. (1993). Characterization and Classification of Isozyme and Morphological Variation in a Diverse Collection of Garlic Clones. Euphytica, 68, 121-130. http://dx.doi.org/10.1007/BF00024161

Pourdad, S. S. (2008). Study of drought resistance indices in spring safflower. Acta Agron. Hung., 56, 203-212. http://dx.doi.org/10.1556/AAgr.56.2008.2.9

Sambrook, J., Fritsch, E. F., \& Maniatis T. (1989). Gel electrophoresis of DNA. Molecular cloning a laboratory manual (2nd ed., pp. 6.3-6.17). Cold Spring Harbor Laboratory Press, New York, USA.

Shao, H. B., Chu, L. Y., Shao, M. A., Abdul Jaleel, C., \& Hong-Mei, M. (2008). Higher plant antioxidants and redox signaling under environmental stresses. Comp. Rend. Biol., 331, 433-441. http://dx.doi.org/10.1016/j.crvi.2008.03.011

Sharma, H. C., Ohm, H., Goulart, L., Lister, R., \& Benlhabib, O. (1995). Introgression and characterization of barley yellow dwarf virus resistance from Thinopyrum intermedium into wheat. Genome, 38, 406-413. http://dx.doi.org/10.1139/g95-052

Yamaguchi, M. (1983). World vegetables: Principles, production and nutritive values. AVI, Westport, Conn. http://dx.doi.org/10.1007/978-94-011-7907-2

\section{Copyrights}

Copyright for this article is retained by the author(s), with first publication rights granted to the journal.

This is an open-access article distributed under the terms and conditions of the Creative Commons Attribution license (http://creativecommons.org/licenses/by/3.0/). 